\title{
Potensi yogurt kacang merah (Phaseolus vulgaris L) ditinjau dari sifat organoleptik, kandungan protein, lemak dan flavonoid
}

\author{
Natalia Desy Putriningtyas", Siti Wahyuningsih
}

\begin{abstract}
Background: Yogurt is one of fermented milk products. Yogurt can also be made from red beans milk (Phaseolus vulgaris L). Red beans milk has a better taste and flavor compared to the other legumes. Red beans are a good source of complex carbohydrates, protein, vitamin B, iron, calcium,phosphorus and also rich in fiber and flavonoids. Red beans yogurt is one of the innovations of fermented red beans products.

Objective: This study was aimed to determine the differences of red beans yogurt on organoleptic properties, protein, lipid and flavonoid contents.

Methods: The study was held in February-September 2017 at Microbiology Laboratory of Center for Food and Nutrition, Gadjah Mada University and Dietetic and Culinary Laboratory of Respati University, Yogyakarta. The study was experimental design using Completely Randomized research Design (CRD) with four treatments, each replicated two times. The formulation of yogurt were A (control from cow milk and 2\% skim milk); B (red beans and 2\% skim milk); $C$ (red beans and skim milk with comparison 1:0.5); D (red beans and skim milk with comparison 1:1). Hedonic scale test form was used for measuring organoleptic properties, such as flavor, taste, texture, colour and overall organoleptic properties. Hedonic level was done by twenty semi trained panelist. The difference of organoleptic properties were analyzed by Kruskal-Wallis test and continued by Mann Whitney U test.

Results: Flavor, color, taste, and texture and overall organoleptic properties between groups were significantly different; $p=0.001$ respectively. The protein, lipid and flavonoid content between groups were not significantly different; $p=0.083 ;$ 0.919; 0.083 respectively. Yogurt $C$ was preferable with a ratio of skim milk to red beans of 1:0.5. The highest protein and fat content was found in yogurt $D$. The highest flavonoid was found in yogurt $C$.
\end{abstract}

Conclusion: There were no differences in protein, lipid and flavonoid content but different in organoleptic properties.

Keywords: yogurt; red beans; organoleptic properties; protein; lipid; flavonoid

\begin{abstract}
ABSTRAK
Latar Belakang: Yogurt merupakan salah satu produk susu fermentasi. Yogurt juga dapat dibuat dari bahan nabati, seperti susu kacang merah (Phaseolus vulgaris L). Susu kacang merah memiliki cita rasa yang lebih enak dan memberikan aroma yang lebih baik dibandingkan kacang-kacangan lain. Kacang merah kaya akan karbohidrat kompleks, protein,vitamin B, zat besi, kalsium, fosfor, serat dan flavonoid. Yogurt kacang merah merupakan salah satu inovasi fermentasi kacang merah.

Tujuan: Menganalisis perbedaan sifat organoleptik, kandungan protein, lemak dan flavonoid yogurt kacang merah pada berbagai formulasi.

Metode: Penelitian ini merupakan penelitian eksperimen dengan rancangan acak lengkap, dilakukan di Laboratorium Mikrobiologi, Pusat Studi Pangan dan Gizi, UGM serta Laboratorium Dietetik dan Kulinari Universitas Respati Yogyakarta pada Februari - September 2017. Formulasi yogurt kacang merah yang digunakan ialah A (kontrol yang berasal dari susu sapi dan 2\% susu skim); B (kacang merah dan 2\% susu skim); C (kacang merah dan susu skim dengan perbandingan 1:0,5); $D$ (kacang merah dan susu skim dengan perbandingan 1:1). Penelitian ini menggunakan formulir hedonic scale test untuk mengetahui sifat organoleptik meliputi aroma, rasa, tekstur, warna dan sifat organoleptik secara keseluruhan kepada 25 panelis semi terlatih. Analisis data menggunakan uji Kruskal-Wallis dan dilanjutkan dengan uji Mann-Whitney.

Hasil: Terdapat perbedaan rasa, aroma, tekstur, warna dan sifat organoleptik secara keseluruhan pada keempat kelompok yogurt $(p=0,001)$. Yogurt yang paling disukai oleh panelis adalah yogurt $C$ dengan perbandingan susu skim dengan kacang merah sebesar 1:0,5. Kandungan protein dan lemak tertinggi terdapat pada yogurt D sedangkan kandungan flavonoid tertinggi pada yogurt $C$. Tidak ada perbedaan kandungan protein, lemak dan flavonoid pada masing-masing kelompok formulasi ( $p=0,083 ; 0,919 ; 0,083)$.

Simpulan: Tidak terdapat perbedaan kandungan protein, lemak dan flavonoid tetapi terdapat perbedaan pada sifat organoleptik pada masing-masingkelompok formulasi yogurt kacang merah.
\end{abstract}

Kata kunci: yogurt; kacang merah; uji organoleptik; protein; lemak; flavonoid

\section{PENDAHULUAN}

Program Studi Ilmu Gizi, Fakultas Ilmu Kesehatan, Universitas Respati Yogyakarta. Jl. Raya Tajem Km. 1,5 Maguwoharjo, Depok, Sleman Yogyakarta.

* Korespondensi: Email: natalia.desy12@gmail.com, HP: 085640885101.
Kata yogurt berasal dari bahasa Turki yang berarti susu asam. Yogurt merupakan hasil olahan susu yang diproses melalui fermentasi dengan penambahan kultur organisme baik. Kultur organisme yang dapat ditambahkan berupa bakteri asam laktat (BAL). Bakteri asam laktat yang biasa digunakan 
ialah kelompok Lactobacillus dan Streptococcus. Bakteri ini mengubah laktosa menjadi asam laktat. Bahan dasar pembuatan yogurt dapat berasal dari susu sapi, susu kambing dan susu skim. Yogurt dapat memiliki berbagai bentuk seperti bentuk semi solid maupun dalam bentuk cair. Penelitian yang telah dilakukan menyatakan bahwa yogurt memiliki beberapa manfaat. Yogurt mengandung suatu faktor yang dapat menghambat sintesis kolesterol sehingga menurunkan kadar kolesterol. Yogurt juga dapat meningkatkan daya cerna dan absorpsi pada saluran pencernaan dikarenakan adanya pertumbuhan BAL Streptococcus thermophilus sehingga merangsang gerakan peristaltik pada saluran cerna. ${ }^{1,2,3}$

Yogurt dapat berfungsi sebagai anti diare sekaligus mencegah aktivitas dan pertumbuhan bakteri patogen. Pertumbuhan bakteri patogen ini dapat dikurangi dengan adanya bulgarican yang dihasilkan oleh Lactobacillus bulgaricus. Bulgarican efektif sebagai antimikroba dalam menghambat organisme patogen. Bakteri asam laktat juga memiliki potensi untuk merangsang sekresi enzim lactase di saluran cerna sehingga dapat membantu para penderita lactose intolerance. ${ }^{4,5,6}$

Yogurt yang biasa berbahan dasar susu dari hewan dapat disubstitusi dengan susu dari kacangkacangan, salah satunya adalah kacang merah. Kacang merah (Phaseolus vulgaris $L$ ) termasuk dalam Famili Leguminoseae alias polong-polongan. Kacang merah merupakan sumber yang baik akan karbohidrat kompleks, protein, vitamin $\mathrm{B}$, zat besi, kalsium dan fosfor. Kacang merah juga kaya akan serat dan flavonoid (proantosianidin dan isoflavon). Serat dalam kacang merah berupa serat larut dan serat tidak larut. Kacang merah memiliki berbagai manfaat serta aman dikonsumsi oleh penyandang Diabetes melitus tipe 2 dikarenakan memiliki indeks glikemik rendah. ${ }^{7}$ Penelitian oleh Shim dkk menyatakan bahwa konsumsi harian isoflavon dengan dosis $3 \mathrm{mg} / \mathrm{kg} \mathrm{BB}$ membantu menurunkan berat badan tanpa menimbulkan hepatotoksisitas dan meningkatkan survival rate pada tikus sprague dawley yang diinduksi STZ. ${ }^{8}$ Isoflavon merupakan salah satu senyawa flavonoid yang banyak dijumpai pada kacang-kacangan. ${ }^{9}$

Pembuatan susu kacang merah hampir sama dengan pembuatan susu dari kacang-kacangan lain. Pembuatan yogurt kacang merah dilakukan dengan penambahan bakteri Lactobacillus yang berfungsi sebagai mikroflora usus dan membantu proses pencernaan. Susu kacang merah memiliki cita rasa yang lebih enak dan memberikan aroma yang lebih baik dibandingkan dengan kacang-kacangan jenis lain. ${ }^{10}$

Yogurt yang terbuat dari sari nabati sebenarnya sangat berpotensi untuk dikembangkan karena disamping nilai gizinya tinggi, harga yogurt sari nabati lebih murah bila dibandingkan yogurt susu hewan. ${ }^{11}$

Rasa, aroma dan tekstur merupakan kunci utama pembuatan yogurt. Pencampuran beberapa jenis bakteri akan mempengaruhi rasa dan aroma yogurt sehingga menghasilkan rasa atau aroma yang khas. ${ }^{10}$ Kandungan gula alami sari kacang merah diketahui sangat terbatas, sementara gula digunakan sebagai sumber karbon untuk memicu pertumbuhan bakteri pada proses pembuatan susu fermentasi. ${ }^{12}$

Pembuatan yogurt kacang merah membutuhkan kombinasi penggunaan susu hewan dan susu kacang merah pada proporsi tertentu, sehingga dapat menghasilkan karakteristik yogurt kacang merah yang sesuai.

Penelitian yang mempelajari sifat organoleptik, kandungan protein, lemak dan flavonoid pada produk fermentasi susu kacang merah masih sangat terbatas. Penelitian ini dilakukan dengan membuat berbagai formulasi yogurt kacang merah yang menggunakan campuran kultur bakteri asam laktat yaitu Streptococcus thermophilus dan Lactobacillus bulgaricus dengan penambahan sukrosa $10 \%$. Tujuan penelitian ini adalah mengetahui perbedaan sifat organoleptik, kandungan protein, lemak dan flavonoid pada berbagai formulasi yogurt kacang merah sebagai salah satu pilihan minuman probiotik.

\section{BAHAN DAN METODE}

Penelitian dilaksanakan pada bulan FebruariSeptember 2017. Penelitian ini merupakan penelitian eksperimen laboratorium dengan rancangan acak lengkap menggunakan empat perlakuan dan dua kali pengulangan. ${ }^{13}$ Formulasi yogurt kacang merah pada penelitian ini yakni: A. Yogurt kontrol yang berasal dari susu sapi dan susu skim sebanyak 2\%; B. Yogurt kacang merah yang berasal dari kacang merah dan $2 \%$ susu skim; C. Yogurt kacang merah yang berasal dari kacang merah dan susu skim dengan perbandingan $1: 0,5$; D. Yogurt kacang merah yang berasal dari kacang merah dan susu skim dengan perbandingan 1:1. Formulasi yogurt pada masing-masing kelompok kemudian dianalisis menurut sifat organoleptik, kandungan protein, lemak dan flavonoid.

Penelitian dilaksanakan pada bulan FebruariSeptember 2017. Laboratorium Mikrobiologi Pusat Studi Pangan dan Gizi Universitas Gajah Mada sebagai tempat pembuatan starter sekaligus yogurt kacang merah, Laboratorium Dietetik dan Kulinari Universitas Respati Yogyakarta untuk pembuatan susu kacang merah, yogurt kacang merah dan pengujian sifat organoleptik serta Laboratorium Pusat Studi Pangan dan Gizi Universitas Gajah Mada untuk pemeriksaan kandungan protein, lemak dan flavonoid. 
Ethical clearance sudah diperoleh sebelum penelitian dilaksanakan dengan nomor 675.4/FIKES/PL/VII/2017.

Pengujian sifat organoleptik terdiri dari warna, aroma, rasa, tekstur melalui uji organoleptik dengan hedonic scale test dengan kriteria penilaian sebagai berikut: $1=$ sangat tidak suka, $2=$ tidak suka, $3=$ suka, $4=$ sangat suka. Semakin tinggi skor penilaian berarti yogurt tersebut semakin disukai oleh panelis agak terlatih yang berjumlah 25 orang. Panelis tersebut adalah mahasiswa Program Studi Ilmu Gizi Universitas Respati semester tujuh dan para analis di Laboratorium Pusat Studi Pangan dan Gizi Universitas Gajah Mada Yogyakarta. Pengujian kandungan protein dan lemak yogurt kacang merah dilakukan dengan metode spektrofotometri sedangkan kandungan flavonoid yogurt kacang merah dengan metode kromatografi gas. Instrumen yang digunakan meliputi timbangan digital, kompor, panci, baskom, blender, sendok, gelas, saringan, kacang merah, susu sapi cair, susu skim, sukrosa, starter bakteri asam laktat (Lactobacillus bulgaricus dan Streptococcus thermophilus), air mineral, alat tulis dan formulir hedonic scale test. Pembuatan starter menggunakan Lactobacillus bulgaricus dan Streptococcus thermophilus yang diinokulasi di dalam susu skim steril selama 24 jam pada suhu $37^{\circ} \mathrm{C}$. Kultur bakteri dimasukkan ke dalam 100 ml larutan susu skim 10\%. Tahapan selanjutnya setelah melakukan pembuatan starter yogurt dilanjutkan dengan pembuatan susu kacang merah. Susu kacang merah berasal dari kacang merah yang direndam selama 12 jam kemudian diblender dengan menggunakan perbandingan air 1:8 kemudian dimasak hingga mendidih. Tahap akhir pembuatan susu kacang merah dengan menyaring hasil blender serta ditambahkan sukrosa $10 \%$ kemudian dididihkan dan didinginkan.

Yogurt kacang merah diperoleh dengan mencampurkan susu skim pada masing- masing formulasi dengan susu kacang merah kemudian dipasteurisasi pada suhu $80^{\circ} \mathrm{C}$ selama 30 menit dengan ditutup menggunakan alumunium foil dan plastik bening. Susu pasteurisasi kemudian didinginkan dan ditambahkan starter yogurt dengan perbandingan 5\% Streptococcus thermophilus dan 5\% Lactobacillus bulgaricus kemudian ditutup kembali dengan alumunium foil dan plastik. Inkubasi pada suhu $42^{\circ} \mathrm{C}$ selama 7 jam untuk mendapatkan yogurt kacang merah sesuai formulasi.

Uji Kruskall Wallis dilakukan untuk mengetahui apakah terdapat perbedaan sifat organoleptik, kandungan protein, lemak dan flavonoid antar kelompok dan dilanjutkan dengan uji Mann Whitney apabila ditemukan ada beda antar kelompok.

\section{HASIL}

Tabel 1 menunjukkan sifat organoleptik yogurt yang berasal dari empat formulasi. Hasil penilaian organoleptik menunjukkan bahwa sebanyak 52\% panelis menyukai aroma dari yogurt $\mathrm{C}$ dan $\mathrm{D}$. Hal ini disebabkan karena pada yogurt $\mathrm{C}$ dan $\mathrm{D}$ tidak terdapat aroma langu.

Tabel 1. Hasil Distribusi Frekuensi Sifat Organoleptik pada Yogurt

\begin{tabular}{|c|c|c|c|c|c|}
\hline \multirow[t]{2}{*}{ Kelompok } & \multicolumn{5}{|c|}{ Distribusi Frekuensi Sifat Organoleptik $(n=25)$} \\
\hline & Aroma & Rasa & Tekstur & Warna & Keseluruhan \\
\hline \multicolumn{6}{|r|}{ 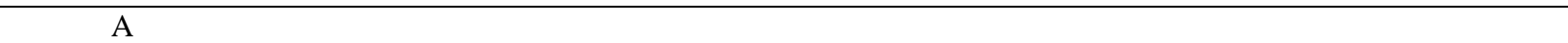 } \\
\hline Sangat tidak suka & 0 & 0 & 0 & 0 & 0 \\
\hline Tidak suka & $1(4 \%)$ & $2(8 \%)$ & $2(8 \%)$ & $2(8 \%)$ & $1(4 \%)$ \\
\hline Suka & $12(48 \%)$ & $11(44 \%)$ & $12(48 \%)$ & $9(36 \%)$ & $12(48 \%)$ \\
\hline Sangat suka & $12(48 \%)$ & $12(48 \%)$ & $11(44 \%)$ & $14(56 \%)$ & $12(48 \%)$ \\
\hline \multicolumn{6}{|l|}{$\mathrm{B}$} \\
\hline Sangat tidak suka & $5(20 \%)$ & $1(4 \%)$ & $1(4 \%)$ & $1(4 \%)$ & $4(16 \%)$ \\
\hline Tidak suka & $15(60 \%)$ & $18(72 \%)$ & $15(60 \%)$ & $10(40 \%)$ & $17(68 \%)$ \\
\hline Suka & $5(20 \%)$ & $6(24 \%)$ & $8(32 \%)$ & $13(52 \%)$ & $4(16 \%)$ \\
\hline Sangat suka & 0 & 0 & $1(4 \%)$ & $1(4 \%)$ & 0 \\
\hline \multicolumn{6}{|l|}{$\mathrm{C}$} \\
\hline Sangat tidak suka & 0 & 0 & 0 & 0 & 0 \\
\hline Tidak suka & $7(28 \%)$ & $3(12 \%)$ & $3(12 \%)$ & $3(12 \%)$ & $4(16 \%)$ \\
\hline Suka & $13(52 \%)$ & $16(64 \%)$ & $14(56 \%)$ & $17(68 \%)$ & $15(60 \%)$ \\
\hline Sangat suka & $5(20 \%)$ & $6(24 \%)$ & $8(32 \%)$ & $5(20 \%)$ & $6(24 \%)$ \\
\hline \multicolumn{6}{|l|}{$\mathrm{D}$} \\
\hline Sangat tidak suka & 0 & 0 & 0 & 0 & 0 \\
\hline Tidak suka & $7(28 \%)$ & $5(20 \%)$ & $14(56 \%)$ & $2(8 \%)$ & $3(12 \%)$ \\
\hline Suka & $13(52 \%)$ & $19(76 \%)$ & $10(40 \%)$ & $18(72 \%)$ & $11(44 \%)$ \\
\hline Sangat suka & $5(20 \%)$ & $1(4 \%)$ & $1(4 \%)$ & $5(20 \%)$ & $11(44 \%)$ \\
\hline
\end{tabular}

A: Yogurt kontrol yang berasal dari susu sapi dan 2\% susu skim; B: Yogurt kacang merah yang berasal dari kacang merah dan 2\% susu skim; C: Yogurt kacang merah yang berasal dari kacang merah dan susu skim dengan perbandingan 1 : 0,5; D: Yogurt kacang merah yang berasal dari kacang merah dan susu skim dengan perbandingan $1: 1$ 
Panelis yang menyukai rasa yogurt kacang merah kelompok D sebanyak $76 \%$ sedangkan kelompok C sebanyak 64\% dan sebanyak $72 \%$ tidak menyukai rasa yang dihasilkan oleh yogurt $\mathrm{B}$. Panelis yang menyukai tekstur yang dihasilkan oleh yogurt $\mathrm{C}$ sebanyak 56\%. Panelis yang menyukai warna yogurt yang dihasilkan sebanyak $72 \%$ berasal dari kelompok yogurt D. Hasil organoleptik secara keseluruhan panelis paling banyak memilih dan menyukai yogurt C. Yogurt C disukai sebanyak $60 \%$ dari 25 orang panelis yang melakukan uji organoleptik.

Hasil analisis perbedaan yogurt kacang merah dari berbagai formulasi dapat dilihat pada tabel 2 .

Tabel 2 menunjukkan hasil uji beda pada keempat kelompok yogurt dan diperoleh hasil $p=0,001 \quad(p<0,05)$ untuk penilaian organoleptik aroma, rasa, tekstur, warna dan sifat organoleptik secara keseluruhan. Hasil ini menunjukkan bahwa terdapat perbedaan aroma, rasa, tekstur, warna, dan sifat organoleptik secara keseluruhan pada keempat kelompok yogurt sehingga dapat dilanjutkan ke uji non parametrik Mann Whitney untuk mengetahui perbedaan antar kelompok.
Tabel 3 menunjukkan bahwa pada kelompok yogurt A dan B menunjukkan terdapat perbedaan signifikan untuk penilaian organoleptik yang meliputi aroma, rasa, tekstur, warna dan sifat organoleptik secara keseluruhan. Hasil penilaian organoleptik ini berbeda dengan hasil penilaian organoleptik yang ditunjukkan oleh kelompok A dan D yang menunjukkan bahwa tidak terdapat perbedaan pada hasil organoleptik secara keseluruhan $(p=0,589)$. Tabel 3 juga menunjukkan bahwa pada kelompok B dan $\mathrm{C}$ menunjukkan ada perbedaan signifikan pada penilaian organoleptik yang meliputi aroma, rasa, tekstur, warna, dan sifat organoleptik secara keseluruhan dengan nilai $p$ masing- masing $p<0,05$. Hasil ini berbeda dengan hasil yang ditunjukkan oleh kelompok B dan D yang menunjukkan tidak ada beda untuk tekstur yang dihasilkan oleh kedua kelompok yogurt B dan D $(p=0,490)$. Hasil uji lanjut Mann Whitney pada kelompok $\mathrm{C}$ dan $\mathrm{D}$ juga menunjukkan bahwa tidak ada perbedaan sifat organoleptik antara yogurt $\mathrm{C}$ dan $\mathrm{D}(p=0,183)$.

Tabel 2. Hasil Uji Beda pada Masing- Masing Kelompok

\begin{tabular}{cccccc}
\hline \multirow{2}{*}{ Kelompok } & \multicolumn{5}{c}{ Mean Rank $(\mathbf{n = 2 5})$} \\
\cline { 2 - 5 } & Aroma & Rasa & Tekstur & Warna & Keseluruhan \\
\hline A & 71,14 & 69,34 & 68,68 & 67 & 66,20 \\
B & 24,30 & 24,52 & 33,14 & 32 & 20,04 \\
C & 53,28 & 59,22 & 63,22 & 50,76 & 53,66 \\
D & 53,28 & 48,92 & 36,96 & 52,24 & 62,10 \\
\hline$p$ & $0,001^{*}$ & $0,001^{*}$ & $0,001^{*}$ & $0,001^{*}$ & $0,001^{*}$ \\
\hline
\end{tabular}

A: Yogurt kontrol yang berasal dari susu sapi dan $2 \%$ susu skim; B: Yogurt kacang merah yang berasal dari kacang merah dan 2\% susu skim; C: Yogurt kacang merah yang berasal dari kacang merah dan susu skim dengan perbandingan 1 : 0,5; D: Yogurt kacang merah yang berasal dari kacang merah dan susu skim dengan perbandingan $1: 1 ; p^{*}$ signifikan, uji Kruskal Wallis

Tabel 3. Hasil Uji Beda Lanjut

\begin{tabular}{cccccc}
\hline \multirow{2}{*}{ Kelompok } & \multicolumn{5}{c}{$\boldsymbol{p}$} \\
\cline { 2 - 5 } & Aroma & Rasa & Tekstur & Warna & Keseluruhan \\
\hline A-B & $0,001^{*}$ & $0,001^{*}$ & $0,001^{*}$ & $0,001^{*}$ & $0,001^{*}$ \\
A-C & $0,009^{*}$ & 0,100 & 0,369 & $0,018^{*}$ & $0,046^{*}$ \\
A-D & $0,009^{*}$ & $0,001^{*}$ & $0,001^{*}$ & $0,024^{*}$ & 0,589 \\
B-C & $0,001^{*}$ & $0,001^{*}$ & $0,001^{*}$ & $0,005^{*}$ & $0,001^{*}$ \\
B-D & $0,001^{*}$ & $0,001^{*}$ & 0,490 & $0,002^{*}$ & $0,001^{*}$ \\
C-D & 1,000 & 0,075 & $0,001^{*}$ & 0,810 & 0,183 \\
\hline
\end{tabular}

A: Yogurt kontrol yang berasal dari susu sapi dan $2 \%$ susu skim; B: Yogurt kacang merah yang berasal dari kacang merah dan 2\% susu skim; C: Yogurt kacang merah yang berasal dari kacang merah dan susu skim dengan perbandingan 1 : 0,5; D: Yogurt kacang merah yang berasal dari kacang merah dan susu skim dengan perbandingan $1: 1 ; p^{*}$ signifikan, uji Mann Whitney

Kelompok A sebagai kelompok yogurt kontrol menunjukkan warna yogurt yang lebih putih apabila dibandingkan dengan kelompok B.Tekstur yogurt yang cukup kental ditemukan pada kelompok D dengan perbandingan kacang merah dan susu skim yang berbanding lurus.
Hasil analisis kandungan protein, lemak dan flavonoid yogurt kacang merah dari berbagai formulasi dapat dilihat pada tabel 4 .

Tabel 4 menunjukkan bahwa kandungan protein dan lemak paling tinggi dimiliki oleh Yogurt D dengan perbandingan susu skim dan kacang merah 
1:1. Kandungan flavonoid paling tinggi dimiliki oleh Yogurt $\mathrm{C}$ dengan perbandingan kacang merah dan flavonoid 1:0,5. Hasil uji beda pada keempat kelompok formulasi yogurt diperoleh hasil $p>0,05$ untuk kandungan protein, lemak dan flavonoid. Hasil ini menunjukkan bahwa tidak terdapat perbedaan kandungan protein, lemak dan flavonoid pada keempat kelompok formulasi yogurt.

Tabel 4. Hasil Uji Beda pada Masing- Masing Kelompok

\begin{tabular}{cccc}
\hline \multirow{2}{*}{ Kelompok } & \multicolumn{3}{c}{ Mean Rank $(\boldsymbol{n}=2)$} \\
\cline { 2 - 4 } & Protein & Lemak & Flavonoid \\
\hline A & 5,5 & 4,0 & 1,5 \\
B & 1,5 & 4,5 & 3,5 \\
C & 3,5 & 4,0 & 7,5 \\
D & 7,5 & 5,5 & 5,5 \\
\hline$P$ & $0,083^{*}$ & $0,919^{*}$ & $0,083^{*}$
\end{tabular}

A: Yogurt kontrol yang berasal dari susu sapi dan $2 \%$ susu skim; B: Yogurt kacang merah yang berasal dari kacang merah dan 2\% susu skim; C: Yogurt kacang merah yang berasal dari kacang merah dan susu skim dengan perbandingan $1: 0,5 ; \mathrm{D}$ : Yogurt kacang merah yang berasal dari kacang merah dan susu skim dengan perbandingan 1 : $1 ; p^{*}$ Tidak signifikan, uji Kruskal Wallis

\section{PEMBAHASAN}

Uji organoleptik yang dilakukan berupa uji kesukaan (hedonic test). Uji ini dilakukan untuk mengetahui tingkat kesukaan panelis terhadap warna, aroma, rasa, tekstur, dan kesukaan terhadap produk yogurt kacang merah secara keseluruhan. Hasil dari uji kesukaan ini menggambarkan tingkat kesukaan panelis terhadap yogurt kacang merah yang diberi perlakuan berbeda. ${ }^{14}$

Aroma langu pada yogurt kacang merah dapat disamarkan dimungkinkan karena kacang merah telah melalui proses perendaman dan fermentasi oleh bakteri asam laktat. Penelitian yang dilakukan oleh Settachaimongkon, dkk mengatakan bahwa protocooperation antara Streptococcusthermophilus merupakan salah satu faktor penting yang berperan dalam proses fermentasi dan kualitas yogurt. ${ }^{15}$ Yogurt merupakan salah satu bentuk produk minuman hasil pengolahan susu yang memanfaatkan mikroba dalam proses fermentasi susu segar menjadi bentuk produk emulsi semi solid dengan rasa yang lebih asam. BAL berpotensi sebagai antikolesterol karena adanya Eksopolisakarida (EPS). ${ }^{16}$ Hidrolisis laktosa menjadi asam laktat oleh aktivitas mikroba meningkatkan keasaman susu yang mengakibatkan koagulasi protein susu dan yogurt memiliki rasa asam. ${ }^{17}$

Tekstur yogurt sangat dipengaruhi dengan berbagai padatan yang merupakan hasil dari proses fermentasi. Yogurt kacang merah pada penelitian ini menggunakan bakteri asam laktat Lactobacillus bulgaricus dan Streptococcus thermophilus dikarenakan adanya hubungan simbiotik antara kedua BAL dan dapat menurunkan waktu fermentasi. Pertumbuhan Lactobacillus bulgaricus dapat distimulasi oleh produksi formate yang dihasilkan oleh Streptococcus thermophilus. ${ }^{18,19}$ Pertumbuhan Streptococcus thermophilus ini distimulasi oleh asam amino bebas dan peptida yang berasal dari produksi susu oleh Lactobacillus bulgaricus. Hal inilah yang dikatakan sebagai hubungan fermentasi sinbiotik. ${ }^{20}$ Pertumbuhan kedua BAL (lactoacillus bulgaricus dan Streptococcus thermophilus) bersifat homofermentatif sehingga menyebabkan asam lebih cepat diproduksi. Proses fermentasi mengakibatkan aktivitas mikroba meningkat, penurunan $\mathrm{pH}$ dan peningkatan kadar asam dalam produk fermentasi. ${ }^{20,21}$

Proses fermentasi juga meningkatkan kualitas organoleptik dan nilai gizi serta menghilangkan beany flavors. ${ }^{21}$ Penelitian ini menunjukkan bahwa terjadi peningkatan kandungan flavonoid dengan adanya kacang merah. Flavonoid merupakan komponen fenol bioaktif yang banyak ditemukan pada buah, sayur dan bagian tanaman. Flavonoid banyak memiliki peran sebagai antioksidan. ${ }^{23}$ Hasil uji statistik menunjukkan bahwa tidak terdapat perbedaan kandungan lemak, protein dan flavonoid pada keempat kelompok formulasi yogurt. Hasil penelitian ini tidak sejalan dengan penelitian yang dilakukan di Yogyakarta pada bulan November 2013 hingga April 2014, yang menunjukkan bahwa penambahan kombinasi tepung kacang merah dan susu skim pada yogurt memberikan pengaruh yang tidak berbeda terhadap kadar asam laktat, pH, lemak, serat kasar, dan viabilitas bakteri asam laktat, tetapi memberikan pengaruh yang berbeda nyata terhadap uji protein. ${ }^{24}$ Hasil ini juga menunjukkan bahwa proses pengolahan dengan fermentasi ternyata dapat meningkatkan aktivitas antioksidan sehingga akan meningkatkan nilai fungsional suatu bahan pangan. Penelitian McCue dan Shetty mengatakan bahwa selama fermentasi terjadi perubahan glycosides yang disertai peningkatan glycosidase dan aktivitas glucuronidase serta pelepasan substansi antioksidan potensial melalui perubahan flavonoids. ${ }^{25}$ Efek langsung dari proses fermentasi adalah peningkatan kualitas protein dan vitamin serta peningkatan nilai cerna protein dan serat. $^{26}$

\section{SIMPULAN}

Yogurt kontrol, yogurt kacang merah dan 2\% susu skim, yogurt kacang merah dengan 0,5 susu skim serta yogurt kacang merah dengan susu skim yang memiliki perbandingan 1:1 menunjukkan ada perbedaan signifikan untuk uji organoleptik yang meliputi aroma, rasa, tekstur, warna dan sifat 
organoleptik secara keseluruhan. Tidak terdapat perbedaan kandungan protein, lemak dan flavonoid pada keempat kelompok formulasi yogurt kacang merah.

\section{SARAN}

Penelitian selanjutnya perlu dilakukan uji baik secara pre klinis ataupun klinis untuk mengetahui manfaat yogurt kacang merah sebagai salah satu inovasi minuman probiotik.

\section{UCAPAN TERIMA KASIH}

Penelitian ini didanai oleh hibah internal Yayasan Pendidikan Respati.

\section{DAFTAR PUSTAKA}

1. Guo Z, Liu XM, Zhang QX, Shen Z, Tian FW, Zhang $\mathrm{H}$, et al. Influence of consumption of probiotics on the plasma lipid profile: a metaanalysis of randomised controlled trials. Nutr Metab Cardiovasc Dis. 2011; 21(11):844-50.

2. Kolapo AL, Olubamiwa AO. Effect of different concentrations of coconut milk on the chemical and sensory properties of soy-coconut milk based yogurt. Food and Public Health. 2012; 2(4):8592.

3. Mohamadshahi M, Veissi M, Haidari F, Javid AZ, Mohammadi F, Shirbeigi E. Effects of probiotic yogurt consumption on lipid profile in type 2 diabetic patients: A randomized controlled clinical trial. Journal of Research in Medical Sciences. 2014; 6:531-536.

4. Robinson RK. Survival of Lactobacillus acidophilus in fermented products. South African Journal of Dairy Science. 2007; 19: 25-27.

5. Cavallini DCU, Suzuki JY, Abdalla DSP, Vendramini RC, Pauly-Silveira ND, Roselino $\mathrm{MN}$, et al. Influence of a probiotic soy product on fecal microbiota and its association with cardiovascular risk factors in an animal model. Lipid Health Dis. 2011; 29:1-9.

6. Scavuzzi BM, Henrique FC, Miglioranza LHS, Simao ANC, Dichi I. Impact of prebiotics, probiotics and synbiotics on components of the metabolic syndrome. Ann Nutr Disord \& Ther. 2014; 1(2):1-13.

7. Thompson SV, Winham DM, Hutchins AM. Bean and rice meals reduce postprandial glycemic response in adults with type 2 diabetes: a cross- over study. Nutrition Journal. 2012; 11(23):1-7.

8. Shim JY, Kim K, Seo B, and Lee H. Soybean isoflavone extract improves glucose tolerance and raises the survival rate in streptozotocininduced diabetic rats. Nutr Res and Pract. 2007; 1(4):266-72.

9. Kao TH, Lu YF, Hsieh HC, Chen BH. Stability of isoflavone glucosides during processing of soymilk and tofu. Food Res Int. 2004; 37:891900.

10. Novia D. Pembuatan yogurt nabati melalui fermentasi susu kacang merah (Phaseolus vulgaris) menggunakan kultur backslop. [Skripsi]. Depok. Universitas Indonesia; 2012.

11. Kumalaningsih $\mathrm{S}$, Pulungan $\mathrm{MH}$, Raisyah. Substitusi sari kacang merah dengan susu sapi dalam pembuatan yogurt. Industria. 2016; 5(2): 54-60.

12. Rahmayuni, Hamzah F, Noviyana F. Penambahan madu dan lama fermentasi terhadap kualitas susu fermentasi kacang merah. SAGU. 2013; 12(1):25-33.

13. Harsojuwono BA, Arnata IW, Puspawati GA. Rancangan Percobaan: Teori, Aplikasi SPSS dan Excel. Malang: Lintaskata Publishing; 2011. hal. 6.

14. Ayustaningwarno F. Teknologi Pangan Teori Praktis dan Aplikasi. Yogyakarta: Graha Ilmu; 2014.

15. Settachaimongkon $S$, et al. Influence of different proteolytic strains of streptococcus thermophilus in co-culture with lactobacillus delbrueckii subsp. Bulgaricus on the metabolite profile of setyoghurt. International Journal of Food Microbiology. 2014; 177:29-36.

16. Horiuchi H dan Sasaki Y. Short communication: Effect of oxygen on symbiosis between Lactobacillus bulgaricus and Streptococcus thermophilus. Journal of Dairy Science 2012; 95(6):2904-2090.

17. Kunaepah, U. Pengaruh Lama Fermentasi dan Konsentrasi Glukosa terhadap Aktivitas Antibakteri, Polifenol dan Mutu Kimia Kefir Susu Kacang Merah. [Tesis]. Semarang: Universitas Diponegoro; 2008.

18. Jakobsdottir G, Nyman M, Fak F. Designing future prebiotic fiber to target metabolic syndrome. Nutrition. 2014; 30:497-502.

19. Adolfsson O, Meydani SN, Russell RM. Yogurt and gut function. Am J Clin Nutr. 2004; 80:24556.

20. Afriani, Suryono dan Haris L. Karakteristik Dadih Susu Sapi Hasil Fermentasi Beberapa Starter Bakteri Asam Laktat yang Diisolasi Dari Dadih Asal Kabupaten Kerinci. [Skripsi]. Jambi: Fakultas Peternakan Universitas Jambi; 2011.

21. Widiyaningsih EN. Peran probiotik untuk kesehatan. Jurnal Kesehatan. 2011; 4(1):14-20. 
22. Kwak CS, Lee MS, Park SC. Higher antioxidant properties of Chungkookjang, a fermented soybean paste, may be due to increased aglycone and malonylglycoside isoflavone during fermentation. Nutr Resch. 2007; 27:719-727.

23. Pinent M, Castell A, Baiges I, Montagut G, Arola L, Ardévol A. Bioactivity of flavonoids on insulin- secreting cells. Inst of Food Tech. 2008; 7:299-307.

24. Stella. Kualitas yoghurt probiotik dengan kombinasi tepung kualitas yogurt probiotik dan tepung kacang merah (Phaseoulus vulgaris L) dan susu skim. [Skripsi]. Yogyakarta: Fakultas Teknobiologi Universitas Atma Jaya Yogyakarta; 2014.

25. McCue P, Shetty K. Role of carbohydratecleaving enzymes in phenolic antioxidant mobilization from whole soybean fermented with Rhizopus oligosporus. Food Biotech. 2003; 17:27-37.

26. Eklund-Jonsson C, Sandberg A, Alminger ML. Reduction of phytate while preserving minerals during whole grain cereal tempe fermentation. J of Cereal Sci. 2006; 44:154-60. 